DOI: $10.2478 /$ aussoc-2020-0007

\title{
Collaboration and Networking in Adult Education and Training. A Case Study
}

\author{
Adél KISS \\ Association Institutio Pro Educationem Transilvaniensis, Romania \\ office@proeducatione.ro
}

\begin{abstract}
The article discusses the analysis of the available resources in the Pro Educatione Network of Adult Education and Training. The study unveils the provided human resources, economic potential, organizational capacities and relationships as well as the surplus by the network of the 15 adult education organizations. The results show that networking brings access to different resources for network members. Half of the network member organizations affirm intense relationships, i.e. they often call for the collaboration of network member organizations for their adult education and training programmes, and significant co-creation activities are taking place. Despite the fact that several network member organizations have limited resources for the operation of adult education, they achieve significant efficiency; in other words, they can reach out to a considerable number of adult learners through their education and training programmes. The analysis identified passive, moderately active, and very active network members. It also identified areas with deficits in networking.
\end{abstract}

Keywords: network, adult education and training, collaboration, network development

\section{Introduction}

Different types of actors (public institutions, higher education institutions, NGOs, public education institutions, companies and enterprises, etc.) provide adult education and training programmes in general (Darrenwald-Merrian 1992), nationwide in Romania (Vintanu 1998), and in Szeklerland (Kiss 2009). The adult education and training programmes are extremely varied; the criteria for quality and professional contents prevail very differently in these programmes. In Romania, the strategic and legal-administrative frames of adult education have been established by a network of public institutions and subordinated bodies (Hatos-Berce 2012). The key operator of the field is the council/authority (CNFPA/ANC), which manages the accreditation of adult education and training programmes according to a given 
methodology. The aim of this actor is to also get involved into the analysis of trends and changes in the field of adult education; it also initiates debates and defines priorities in the field. These, however, function on central, decisional-executive level; the regionally subordinated bureaus of this council/authority appear as appliers of the accreditation methodology, while they neglect the professional "hosting" of the field. On the local or regional level, one might meet actors who undertake the role of professional hosts (who initiate research, debates, networking, strategic planning and organization, elaboration of own quality assurance frameworks, etc.) in one segment or several related areas of adult education (e.g. social care), but this is not a very common characteristic of the field. Adult education providers - running either accredited or non-accredited programmes - act rather individually, and competition can be traced to various extent (Sava 2008, Papp Z. 2005, Kiss 2009).

The Institutio Pro Educationem Transilvaniensis Association (Pro Educatione) - Network of Adult Education and Training ${ }^{1}$ was founded in 2011 in the social environment described above. It filled and continues to fill a collaboration gap in church-related adult education and training. According to its mission, it "guides the network member organizations' work with professional standards, providing them theoretical and empirical knowledge, and supports their work in spiritual, intellectual, and material respects" (Organizational Strategy: 2). ${ }^{2} 15$ organizations - church-related adult education providers - have joined the network, and several external (regional, national, international) professional relations have been established during the past years. There are regular programme offers for network member organizations (meetings, further education, joint projects). Besides these, there are jointly elaborated adult education and training programmes offered by the network for target groups of the local society. Network meetings are held for the network member organizations' representatives, staff, and delegates and represent opportunities for professionals' lifelong education and relationship development. In addition, these meetings are collective self-reflection processes, which also serve continuity and change in the network (Alke 2018). The adult education and training programmes offered to society aim to have social effects such as promoting and facilitating adult learning from several aspects.

In 2019, a survey was carried out among the 15 network member organizations, in the context of which we assessed their human resources, organizational frameworks, economic potentials, relationships and collaborations, and the perceived surplus provided by the network. The following analysis presents the results of this research.

1 It unites the Christian adult education and training providers of the Roman Catholic Archdiocese of Alba Iulia. Territorially, it covers a broad area in Transylvania; the member organizations of the network offer adult education programmes in the Szeklerland area, i.e. in Harghita, Covasna, and Mureş counties of Romania. 


\section{The Network and Its Adult Education and Training Practice}

Pro Educatione calls itself an adult education network. The literature defines adult education as a "complex of activities aiming towards the conscious and purposeful development of adults in which emphasis is placed on the cultivation of determined competences. In a narrower meaning, adult training is the - usually officially recognized - professional training, further education, and retraining of adults" (Benedek et al. 2002: 163). ${ }^{3}$

Within the adult education programmes provided by the network, most attention is given to the development of professional competences (planning of adult education and training, organization and management, development of trainer and lecturer competencies, etc.) - the network member organizations' staff and delegates get further education in these fields. On the other hand, trainings both aiming to cultivate predetermined competences in a given profession and to answer the social needs of the population have priority among all adult education and training content initiated by the network member organizations when it comes to the internal support of the programmes. However, over the years, non-formal education programmes have also become popular in the network.

Table 1 presents the network member organizations' adult education programme options (types), based on our own categorization. It can be seen that there is a relatively low number (36) of formal, long-term trainings (that offer nationally recognized diplomas $)^{4}$ compared to the short-term non-formal adult education offers (104 in total), which are not necessarily recognized with diplomas. Continuing the above definition, adult education is somewhat broader, more comprehensive than adult training and can expand to more areas of adult life besides the professional career. As per the UNESCO Convention's definition, in adult education, adults "further develop their skills, enrich their knowledge, perfect their technical and professional competences, or retrain themselves in a new direction" (Farkas 2013). ${ }^{5}$ Essentially, the Pro Educatione network has adult education and training programmes in both respects.

3 Author's translation.

4 For example, trainings that are between 120 and 360 hours long.

5 Author's translation. 
Table 1. Network member organizations' adult education and training offer (year 2018)

\begin{tabular}{|c|c|c|c|c|}
\hline \multirow{3}{*}{$\begin{array}{l}\text { Network member } \\
\text { organizations }^{6}\end{array}$} & \multirow{3}{*}{$\begin{array}{c}\begin{array}{c}\text { Accredited } \\
\text { programmes }^{7}\end{array} \\
\text { Formal }^{9} \\
\end{array}$} & \multicolumn{3}{|c|}{ Non-accredited programmes ${ }^{8}$} \\
\hline & & & \multicolumn{2}{|c|}{ Non-formal $^{10}$} \\
\hline & & Long-term & Short-term & Informal $^{11}$ \\
\hline CaritasRURAL & 7 & 0 & 7 & 3 \\
\hline CaritasSCHOOL & 6 & 2 & 3 & 0 \\
\hline CaritasSOCIAL & 0 & 0 & 6 & 1 \\
\hline FamilyPASTORAL & 0 & 0 & 9 & 2 \\
\hline BibleSOCIETY & 0 & 0 & 4 & 11 \\
\hline KolpingFAM & 0 & 0 & 1 & 8 \\
\hline HelpingSISTERS & 0 & 0 & 0 & 5 \\
\hline PastoralBUREAU & 0 & 1 & 1 & 4 \\
\hline ScoutORG & 0 & 1 & 0 & 0 \\
\hline St.GellértFOUND & 0 & 0 & 6 & 3 \\
\hline ÁradatASSOC & 0 & 3 & 12 & 3 \\
\hline HálóASSOC & 0 & 1 & 1 & 6 \\
\hline KalotASSOC & 2 & 9 & 2 & 1 \\
\hline YouthPASTORAL & 0 & 3 & 1 & 1 \\
\hline BibliodramaASSOC & 0 & 1 & 3 & 0 \\
\hline Total & 15 & 21 & 56 & 48 \\
\hline
\end{tabular}

Before presenting the results of the survey on these 15 organizations, I shortly overview the development of adult education and training in Romania, and I will outline some conclusions regarding the role of networking in the case of adult education provider organizations.

6 All the organizations of the Pro Educatione network are non-profit and non-governmental organizations.

7 Adult education and training offers providing nationally recognized diplomas.

8 Adult education and training programmes that do not offer nationally recognized diplomas; however, they can issue a certificate of participation or a locally/regionally recognized diploma.

9 For example: training of home care professionals, acolyte and lecturer training, team leader training, method-specific bibliodrama training, computer-based graphic designer training, hospital nursing assistant training, professional beekeeper training, development of entrepreneurial competences, etc.

10 For example: fruit tree pruning, bibliodrama assistant training, development of entrepreneurial competences, production of matured cheese, biblical theologist training, pre-marriage training courses, scouting basics for adults, mental health training, abuse prevention training, further training for caretakers of mentally disable persons.

11 For example: spiritual retreats, conferences, summer camps, meditations, pilgrimage, sacral art programmes. 


\section{The Social History of Adult Education and Training}

\section{National Situation Report}

The changing economic structure that followed the regime change made the participation in the labour market extremely difficult for the Romanian population during the '90s. Very few have managed to quickly and durably find their place on the labour market (Biró-Laki 2001), masses being forced to continuously seek out alternative adaptation methods to succeed (Sandu 1999, Schifirneț 1997). The lack of training and competences necessary to cope with the changing economic system proved to be an impeding factor in this situation. The educational system could not really find answers to these problems, the adult education system being only able to slowly and partially solve the challenges. According to Papp Z. (2005), especially between 1990 and 1994, but in fact during the entire period of the 90s, adult education meant the training of unemployed persons and reintegrating them into the labour market. Later (around 2001), besides "adult education", there appeared new denominations as well such as "lifelong learning", while by the year 2004 a more holistic interpretation of adult education had evolved besides the professional training of unemployed persons. Consequently, a regulation for the accreditation of adult education and training was established.

According to Sava (2008), these latter changes have taken place due to the urge of legal harmonization duties of the EU pre-accession period. The institution managing the registration and accreditation of adult education and training programmes was created. ${ }^{12}$ Sava has made a first analysis of the registrations made in the first year, from which she concluded that: adult education and training is no longer the instrument for the elimination of unemployment but rather a business (Sava 2008). On the national level, there is created an appropriate adult education system, which is, however, not yet followed by a corresponding social interest. A qualitative study conducted within leaders of adult education and training institutions came to similar conclusions: adult education and training initiatives are more enterpriselike in their operation (Papp Z. 2005), but the adult education and training system is practically unexploited. Szeklerland (and several other rural regions as well) fall behind the national average when it comes to the use of learning opportunities offered by the adult education and training system (Biró-Blága 2019).

Following the country's accession to the European Union in 2007, adults and organizations involved in adult education were given the opportunity to call for funds (within the EU Lifelong Learning Programme) for supporting adult education and learning. At certain levels and to a certain extent, this system had an inspirational/motivational effect in adult education and training: more adults took part in trainings, non-government organizations obtained support for their 
adult education projects, and public and higher education institutions ran applied research projects in the field of adult education. The adult learner and lifelong learning received more focus. Participation is, however, still not high enough to exploit/utilize the system to the maximum.

Based on the Adult Education Survey's (AES) 2017 dataset, ${ }^{13} 1.1 \%$ of Romania's population between ages 25 and 64 took part in adult education and training at the time of asking or within a period of 4 weeks before it. With this value, the country is almost in the last place at the EU level (the EU average in 2017 was 10.9\%). Romania's situation is somewhat more favourable when it comes to asking (from the same population between the ages of 25 and 64) if they took part in any adult education programmes in the last 12 months. According to the 2016 AES survey, this ratio is at $7 \%$, which continues to be the lowest in the EU (where the average of the 28 countries is $45.1 \%$ ). As regarding participation in adult training pertaining to work or job-related activities, the result is more favourable: $60.9 \%$ took part in such programmes, while the EU average is 69.7\%. Based on AES information, jobrelated learning is more characteristic of people above the age of 45 (compared to younger age-groups), among highly educated people, while women have a higher participation ratio than men in adult education in Romania.

\section{Regional Characteristics and Specificities That Affect Adult Education}

Szeklerland, located in the middle of the country, is a rural region where social changes happen both as a result of external effects and due to endogenous initiatives. When external constrains or pressures decrease, certain rehabilitation processes set in motion; and with all of these the internal social patterns get reorganized (Biró 2013). If we approach the regional adult education and training practices from an institutional development point of view, we can see that during the one and a half decade after the regime change, regional institutions experienced the plurality of contexts as well as the variety of opportunities (Oláh 2006: 8). ${ }^{14}$ Strengthening pragmatism in institution leadership, conscious activities aiming towards gaining the support of the local society, the dynamisms of certain fields, the latent tensions and competitions, the more complex tacit knowledge, and advanced experiences were observed. All these have developed as the result of autonomous learning processes since in lack of management trainings the institutions served as their own schools (Oláh 2006).

An analysis of adult education and training programmes accredited between 2004 and 2008 was conducted in Harghita County in 2009. In this period of time, a total of

13 https://ec.europa.eu/eurostat/statistics-explained/index.php/Adult_learning_statistics.

14 Oláh conducted a research among cultural institutions, and his study provides relevant information for adult education as well. 
151 adult education and training programmes were accredited. $36 \%$ of organizations/ institutions applying for accreditation were companies, $29 \%$ were non-governmental organizations, and $35 \%$ were budgetary institutions ${ }^{15}$ (Kiss 2009). $71 \%$ of the accredited adult education programmes were professional training programmes ${ }^{16}$ (the remaining part was made up of introductory or specialization training programmes). In what regards their contents: the majority of them were so-called technical-industrial professional training programmes pertaining to a certain industrial field, but the ratio of language and info-communication competence trainings was also significant, and so was the ratio of trainings pertaining to the service sector. The survey was repeated in April 2011, and the results were as follows: the need for accreditation of adult education and training programmes was increasing; mostly companies and enterprises continued to hold accredited trainings (42\%). The number of adult education and training programmes pertaining to the service sector was growing (Kiss 2019). Besides the accredited adult education and training programmes, a wide offer of non-formal further education and training was present and available for adults in the region.

Moving from the institutional side to the consumers' side of adult education, we present excerpts from regional household surveys (Biró-Laki 2001; Centre for Regional and Anthropological Research - Working Paper, 2005). These surveys - conducted in both rural and urban areas - showed that half of the interviewed population no longer considers themselves competitive in the labour market with the competences and professional knowledge they currently have. In addition, $33 \%$ consider that with their current professional knowledge and experiences they have at best moderate chances in the labour market. After studying background variables, researchers concluded that the regional society is forced to learn. The survey further predicted the increasing number of people recognizing the necessity/compulsion of learning.

Another survey conducted in Harghita County discovered the different aspects of adult learning. The summary of research results states: younger age-groups with a high level of education and living in urban environments and women are generally more actively engaged in adult learning activities, and their ratio of participation in adult learning is increasing (Kiss 2011). Learning motivations are mainly existential and interest-based, while learning needs are diverse. Participation in adult training is successful since the obtained knowledge, the diploma, or the relationships formed during trainings can be put to good use. These are favourable experiences that can give an impulse to adult learning. Respondents' future plans to participate in adult education try to comply with labour market requirements.

15 This distribution follows the national tendency, where $51 \%$ of accredited training programmes were run by companies and enterprises, $20 \%$ by non-governmental organizations, and $29 \%$ by budgetary institutions (Sava 2008) in the same period of time.

16 Adults' professional training in accordance with national regulations can take the following forms: introductory training, professional training, further training (perfection), specialization, and retraining. 


\section{Networking in Adult Education and Training. A Few Empirical Results}

Lately, the intensification of collaborations between adult education providers can be observed, while the collaborations between adult education and other non-government actors, businesses, or cultural organizations have also become widespread in Europe in the last two decades (Alke 2018). In the following, I will present excerpts from research studies carried out among adult education and training organizations participating in networks. According to a survey conducted in Denmark (where 35 non-governmental organizations were connected within a network), the organizations had very high expectations regarding networking (Ostergaard 2005). Besides the intention to increase organizational capacity, the main reasons for joining the network were obtaining information and building relationships. Most of these organizations had no previous network collaboration experience, so they could not really assess the real costs of networking. Researchers found that the main factors that made networking attractive were relevant topics and professional content and results/information usable in the foreseeable future. Since most organizations expected the satisfaction of their informational needs and the development of their organizational capacities from networking, researchers believed that joining the network was a strategic decision for these organizations (Ostergaard 2015).

Alke (2018) researched an adult education and training network located in Germany, which connected 45 organizations. Based on this research, the author points out the following: the successfulness of joining a network depended greatly on the dedication of the operators and the quality of the relationships between them. Trust was a key factor, through which collective identity and stable bonds were formed. The author worked with the notions of stability/continuity and flexibility/ change. Network collaborations (that Alke saw as learning opportunities) might be the creators of stability/continuity and at the same time indicators of the network's level of flexibility/change. The research showed that network collaborations happen on a broad spectrum: from administration to the elaboration of education content, further education of employees, lobbying activities, representation of interests, funding, marketing activities, etc. Organizations used the network to fulfil their own missions and activity plans; network membership and the system of relationships formed through networking were integral part of the organizational self-image. The network maintained and reproduced itself via collaborations and strengthened its common identity. Besides organizational reflections, a collective self-observation was also operated at the network level and was implemented among the developments. According to the author's conclusion, both stability/ continuity and flexibility/change could be observed in the collaboration culture of adult education organizations. 
According to another survey conducted in Australia, adult education institutions face, on a global level, the need to change their wide educational offers into a narrower one, targeting a more specific market slice (Clayton et al. 2008: 13). Organizational culture and structure are the driving forces behind organizational survival during times of change, especially in a world and environment where change is the status quo. The ability of how fast an organization can make steps to be profitable in a competitive environment is a key organizational tool. This also requires that, instead of being hierarchical and bureaucratic, the organizational structure needs to be flat, organic, and network-like (Clayton et al. 2008). One result of the mentioned research is that the more independent training organizations are from the state, the more necessary it is for them to become resilient enterprises. In most organizations, leaders and managers learn this entrepreneurial attitude, so their organizations become more similar to an innovative enterprise. It is advantageous for these organizations to form a network or take the shape of a matrix - i.e. to have hybrid organizational structures (Hunter 2002) because in this way they can be more efficient.

According to Hunter (2002), structural dimensions may and must be changed for the better achievement of goals. In reality, structural changes can take away attention and energy from real goals and tasks. Although network organizations deem change to be basically positive (like something bringing additional income or that can be seen in organizational performance), adaptation to change is not experienced in the same way by these organizations.

\section{Results of Our Empirical Research}

\section{Human Resources of Network Member Organizations}

We analysed how many full-time employees, part-time workers, and contracted external collaborators and volunteers organizations have. Through this, we reveal a part of the adult education organizations' human capital. The human resources are of key importance for organizational initiatives and implementation but also for obtaining a competitive advantage (Becker-Gerhart 1996). The number of employees is a decisive factor in organizational capacity, and the external collaborators and trainers represent the professional relationship network of an organization. Volunteers represent the capacity of adult education and training to be presented as a social value for which people can stand for. Volunteers can be silent partners in adult education (Sandlin-Clair 2004) or can be social entrepreneurs (Clayton et al. 2008): people who "are dedicated to an innovative idea triggering social change, and have the entrepreneurial instinct to achieve it" (Szigeti 2003: 12). ${ }^{17}$ 
Table 2 presents the state of human resources of the Pro Educatione network member organizations. Compared with data from Table 1, we can observe a correlation between the number and length of adult education programmes and the human resources available by organizations. Network member organizations operate with an average of 2.9 employees. Organizations with more employees than the average have complementary activities (usually services) besides their adult education offers (e.g. they engage in counselling, write applications, etc.). Furthermore, their long-term, high-fee, accredited courses outline a business-like character. In comparison, organizations with only 1-3 employees are more active in organizing non-formal adult education programmes (in most of them, communitybuilding appears to be a key element). In the case of three organizations, we also found a significant number of contracted external collaborators besides the employees. These organizations offer adult education programmes on a broad spectrum, i.e. from short-term non-formal to long-term accredited courses. Two organizations neglect to engage volunteers for their activity; they are rather market-oriented in their adult education practices. Where non-formal adult education dominates, there is a significant volunteering human resource.

Table 2. Human resources of the Pro Educatione network member organizations

\begin{tabular}{lccc}
\hline & Employees & $\begin{array}{c}\text { External } \\
\text { collaborators }\end{array}$ & Volunteers \\
\hline ScoutORG & 2 & 4 & 20 \\
\hline YouthPASTORAL & 4 & 0 & 40 \\
\hline CaritasRURAL & 9 & 1 & 0 \\
\hline St.GellértFOUND & 1 & 0 & 3 \\
\hline HálóASSOC & 2 & 0 & 85 \\
\hline KalotASSOC & 2 & 60 & 3 \\
\hline ÁradatASSOC & 2 & 25 & 36 \\
\hline CaritasSCHOOL & 9 & 15 & 0 \\
\hline HelpingSISTERS & 2 & 2 & 30 \\
\hline BibleSOCIETY & 1 & 4 & 12 \\
\hline PastoralBUREAU & 1 & 4 & 35 \\
\hline FamilyPASTORAL & 4 & 0 & 40 \\
\hline KolpingFAM & 2 & 2 & 10 \\
\hline BibliodramaASSOC & 0 & 6 & 325 \\
\hline CaritasSOCIAL & 189 & 5 & $\mathbf{6 4 4}$ \\
\hline Total & $\mathbf{2 3 0}$ & $\mathbf{1 2 8}$ & \\
\hline
\end{tabular}




\section{Organizational Frameworks and Documents}

With the questions belonging to this section, we intended to reveal how formalized the network member organizations' operation is. Framework papers are preconditions and definers of organizational structure, the combination of these papers indicating more complexity and structured ways of implementing the strategy (Antal 2009). When competitive pressures and demands for accountability appear, the existence of well-applicable framework documents are preconditions for professionalism (Hwang-Powell 2009). "Towards a growing knowledge orientation points the tendency of more frequent use of strategic plans, independent financial audits, and quantitative programme evaluations which help to measure and formalize the activities of non-profit organizations" (Dobrai-Farkas 2010: 898). Theses of contingency theory are applicable; the optimal organizational structure depends on contingency factors. We see Pro Educatione network member organizations as actors whose organizational structures have evolved conform to their environment.

The results showed that there are marked differences between the network member organizations when we check the documents framing and supporting organizational operation. In church structures, there are cases where adult education and training programmes work under the aegis of certain church bodies (for example: parishes). In the case of two network member organizations, we found that they do not have an independent legal person (this is the reason why they do not adopt own organizational rules of procedures and annual financial balance sheets). After these basic operational documents, we think the organizational strategy is of key importance. As data show, two-thirds of the network organizations have this document; so, they use this methodology "by which a specific roadmap is recognized for growing a doable, coherent and strong business or organization" (Hall 2013: xi).

The lack of organizational strategy of a few actors points to an environmental characteristic, meaning an organizational developmental delay that appears in several respects in church-related environments and which means the operation of simple organizational structures (Mintzberg 1981). Activity planning, budget planning, and reporting relate to professional content and provide the basics for accountability. In this respect, network member organizations appear to be more skilful (budget planning is maybe a field where joint practice could foster catching up with some actors). At half of the organizations, we found the functioning of an "own” quality assurance system. Such systems originate from the organizations' external "parent" organization (or from a collaboration with an important partner), from whom the organizations learn and take over knowledge.

Economic activities can be interpreted as actions to create support structures (financial backgrounds) for organizations. These are quite rare in the network. Where such activities exist, income is generated through training services, exchanges of 
experience, giving lectures, participation in various projects, training courses, realestate leasing, and product sales (e.g. book sales).

To conclude, there are certain areas where organizations of the network can learn from each other and can help each other in order for the fundamental requirements of professional operation to be created (where these are missing) and in order to achieve further development (where these are needed).

Table 3. Organizational framework documents

\begin{tabular}{|c|c|c|c|c|c|c|c|c|c|}
\hline & $\begin{array}{c}\text { A - } \\
\text { Strat. }\end{array}$ & $\begin{array}{c}\text { B - } \\
\text { Rules. }\end{array}$ & $\begin{array}{c}\text { C - } \\
\text { Qualit. }\end{array}$ & $\begin{array}{c}\text { D - } \\
\text { Econ. }\end{array}$ & $\begin{array}{c}\text { E - } \\
\text { Legal P. }\end{array}$ & $\begin{array}{c}\text { F - } \\
\text { Balance }\end{array}$ & $\begin{array}{c}\text { G - } \\
\text { Budg. }\end{array}$ & $\begin{array}{c}\text { H - } \\
\text { Act. P. }\end{array}$ & $\begin{array}{r}\text { I - } \\
\text { Rep. }\end{array}$ \\
\hline ScoutORG & 1 & 1 & 1 & 0 & 1 & 1 & 1 & 1 & 1 \\
\hline YouthPASTORAL & 1 & 1 & 1 & 0 & 1 & 1 & 1 & 1 & 1 \\
\hline CaritasSOCIAL & 1 & 1 & 1 & 0 & 1 & 1 & 1 & 1 & 1 \\
\hline St.GellértFOUND & 0 & 1 & 0 & 1 & 1 & 1 & 1 & 1 & 1 \\
\hline HálóASSOC & 1 & 1 & 1 & 0 & 1 & 1 & 1 & 1 & 1 \\
\hline KalotASSOC & 1 & 1 & 0 & 1 & 1 & 1 & 0 & 1 & 1 \\
\hline ÁradatASSOC & 1 & 1 & 0 & 1 & 1 & 1 & 1 & 1 & 1 \\
\hline CaritasSCHOOL & 1 & 1 & 1 & 1 & 1 & 1 & 1 & 1 & 1 \\
\hline HelpingSISTERS & 0 & 1 & 0 & 0 & 1 & 1 & 1 & 0 & 0 \\
\hline BibleSOCIETY & 0 & 1 & 1 & 0 & 1 & 1 & 0 & 1 & 1 \\
\hline PastoralBUREAU & 0 & 0 & 0 & 0 & 0 & 0 & 0 & 0 & 0 \\
\hline FamilyPASTORAL & 0 & 0 & 0 & 0 & 0 & 0 & 0 & 1 & 1 \\
\hline KolpingFAM & 0 & 1 & 0 & 1 & 1 & 1 & 0 & 1 & 1 \\
\hline BibliodramaASSOC & 1 & 1 & 1 & 0 & 1 & 1 & 1 & 1 & 1 \\
\hline CaritasRURAL & 1 & 1 & 0 & 1 & 1 & 1 & 1 & 1 & 1 \\
\hline
\end{tabular}

\section{Economic Aspects and Potentials}

Researchers agree on the tendency that the financial resources of the non-profit sector are becoming scarce (Capozzi et al. 2003), while they meet the increasing pressure coming on the part of for-profit or state institutions (these become competitors Ryan 1999), supporters, media or target groups (Burt-Taylor 2000, McHargue 2003). They will come under pressure to perform higher-quality work from less resource, an impetus to learn the conscious management of knowledge (Farkas-Dobrai 2009). The success of NGOs is determined by sector-specific characteristics.

Considering the management of financial capital by the network member organizations, we reflect on two variables: project budgets and the origins of their funds. We think project budgets are indicative of the experience of organizations in running small-scale or large-scale adult education projects, while the origins 
of their funds speak about their knowledge and practice of fundraising via grant applications. In the questionnaire, we defined threshold values (these are rather internal indicative values, based on our practical experiences in the financial management of adult education projects in our environment): budgets for adult education projects larger than EUR 5,000 and budgets for adult education projects larger than EUR 10,000. Results confirm that the majority of adult education and training programmes operated by network member organizations fall into a lowbudget category. Four out of the 15 organizations reported having recently project budgets larger than EUR 10,000 for adult education.

All organizations practice fundraising, all of them used to apply for funds available within the country. Application for foreign funds is also in practice; only two organizations have no experience in this regard. As regards the financial resources available for adult education and training, the contribution of participants/adult learners is significant. Furthermore, foreign supporters and external/international resources are also important, being in service and support of adult education. The field of economic resources and potentials is wider and more complex; these two variables highlighted only two patterns of financial knowledge management.

Table 4. Project budgets and the origin of funds (where organizations apply for)

\begin{tabular}{lcccc}
\hline & $\begin{array}{c}\text { Project budget } \\
\text { larger than EUR } \\
\mathbf{5 , 0 0 0}\end{array}$ & $\begin{array}{c}\text { Project budget } \\
\text { larger than EUR } \\
\mathbf{1 0 , 0 0 0}\end{array}$ & $\begin{array}{c}\text { Applies to } \\
\text { national/ } \\
\text { domestic funds }\end{array}$ & $\begin{array}{c}\text { Applies to } \\
\text { international } \\
\text { funds }\end{array}$ \\
\hline ScoutORG & 1 & 0 & 1 & 1 \\
\hline YouthPASTORAL & 1 & 0 & 1 & 1 \\
\hline CaritasSOCIAL & 1 & 1 & 1 & 1 \\
\hline St.GellértFOUND & 0 & 0 & 1 & 1 \\
\hline HálóASSOC & 1 & 1 & 1 & 1 \\
\hline KalotASSOC & 1 & 1 & 1 & 1 \\
\hline ÁradatASSOC & 1 & 0 & 1 & 1 \\
\hline CaritasSCHOOL & 1 & 1 & 1 & 1 \\
\hline HelpingSISTERS & 0 & 0 & 1 & 1 \\
\hline BibleSOCIETY & 0 & 0 & 1 & 1 \\
\hline PastoralBUREAU & 1 & 0 & 1 & 1 \\
\hline FamilyPASTORAL & 1 & 0 & 1 & 0 \\
\hline KolpingFAM & 0 & 0 & 1 & 0 \\
\hline BibliodramaASSOC & 0 & 0 & 1 & 1 \\
\hline CaritasRURAL & 0 & 0 & 1 & \\
\hline
\end{tabular}




\section{The Social Network of Adult Education Organizations}

When mapping the social networks that adult education organizations have, we were interested in the ratio of relations with organizations having similar and different profiles and the origin (domestic or foreign) of their partner/collaborator organizations. Based on the answers, we can say that the Pro Educatione network member organizations are in intense professional relationships with domestic adult education providers. Half of the organizations report about collaborating with actors having similar profiles. This is an indication regarding the fact that segments of adult education are collaborative and complementary to each other. In a previous chapter, we mentioned the competitive character of the field. This result rather explains cooperation and even co-creation activities with professional purpose that have a potential to lead to joint competitive advantage. Half of the network member organizations mention collaborations with partners outside of the field of adult education. According to their evaluation, these seem to be impactful collaborations, meaning partnerships in different activities, usually in the fields of community development, counselling, rural development, youth support, pastoral work, and social care. These are possibilities for adult education providers to enlarge their professional fields, for knowledge acquisition, for serving as background support or promotion of knowledge production.

Considering the origin of partner organizations in the network, the practice of collaboration with foreign partners is rather an untapped potential. Ten organizations reported having such connections, but only a few actors practised collaboration in adult education projects more intensively, on a regular basis. Others keep the relationships rather formal, on a protocol level. The survey revealed that the relations with professional partner organizations and sponsors were deemed to have a lesser degree of importance. The most votes were given to the organizations' relationship with adult learners. ${ }^{18}$ Similarly to adult learners, external collaborators (trainers, lecturers, and professionals) were of high importance within the social capital of network member organizations.

Furthermore, we asked network member organizations to evaluate the relationships they have within the network. Based on the answers, we can confirm several relationships that are considered intensely active. Most actors reported, however, a dormant type of relationship (being present for each other but not active or manifest enough). This indicates that there is still space for encouraging further collaborations within the network.

18 We asked network member organizations to estimate how many adult learners they reached through their adult education and training programmes in 2018. Each organization reported about hundreds of participants, indicating that about 11,000 persons/adult learners attended in total the courses and trainings offered by the network member organizations. 


\section{The Perceived Surplus Provided by the Network}

We measured the surplus provided by networking by asking the organizations to evaluate on a scale of 1 to 6 to what degree they felt that material gain, relationship growth, professional knowledge generation, community development, and lobbying activities were taking place within the network. We calculated the average value of the answers provided, and so we obtained that organizations consider lobbying for common goals the most accomplished task (the average value of this item is 4.55). In our interpretation, this result shows that the network has strength in representing common values and goals and has the potential to intervene in the interest of Catholic adult education. Relationship growth is the second highly rated item (average: 4.36), meaning that networking is a real chance for creating, cultivating, and utilizing professional relationships. The growth of professional knowledge (average: 4.27) is also a well-traceable realization and result of networking. Networking in practice leads not only to increased visibility and social capital but to better performance as well. Community development is an item that also received better rating (average value: 4.18), an outcome that shows the added value of networking in the forming of a professional community.

The lowest rating was given to the growth of material capital (average value: 3.18). The support of network member organizations in material respects is a tertiary aim in the organizational strategy. There are advances in this field as well; however, this is a segment that is desired to be more efficient. In overall, we can say that networking is perceived as access to different types of resources.

Finally, we asked network member organizations about their satisfaction with the network's joint projects and activities. On a scale of 1-5, the average value was 3.8. Three organizations expressed their complete satisfaction. Others mentioned the need for higher degrees of professionalism - namely: they expect quality assurance guidelines; learning and development opportunities personalized for each organization; they require more lobbying activities. Furthermore, organizations expect more intense relationships, further common programmes and projects, more openness for sharing of professional content, the stimulation of accounting and reporting, and more intensive participation in meetings. Additionally, there are financial/material expectations as well, in the context of which the need for the development of support structures was expressed. 


\section{Conclusions}

The article discussed the available resources in the Pro Educatione Network of Adult Education and Training. As we have seen in the multi-actor field of adult education, it is a challenge being the professional "host" of the field. The national context of adult education provides complex and multiple structures that prove to be unexploited by social demands. Besides this, the regional context is characterized by social barriers and disadvantages specific to rural regions. The Pro Educatione Network of Adult Education and Training is filling a gap in two respects: one is related to organizational development (the network is a background support of developmental incentives for adult education providers), while the other refers to the social behaviour related to adult education and responds to the educational demands and needs of the society.

Our study conducted on the network unveiled that where and when network member organizations have more human resource at disposal, they offer adult education programmes on a broad and formal spectrum, while those in shortage of human resource are more likely orientated towards small-scale, non-formal educational offers. Network member organizations are in advanced progress towards an adequate level of formalization, setting up the conditions of accountability. In economic terms, networking turns out to be a stabilizer in competition and a pressure to intensify learning in financial management. Social relations and connectedness are more intensively realized. Internal collaborations result in professional co-creations, while networking contributed to the evolution of intensive professional hubs (Barabási 2013). The external relations (considered mainly protocollar relations) prove to be channels to knowledge and projects. We consider that the network member organizations are efficient in their ability to reach out to a considerable number of adult learners (over 11,000 people) each year through their education and training programmes. While networking means extra efforts for organizations (Alke 2018), it is an environmental effect that shapes the evolution of organizational development (Mintzberg 1989). Network member organizations describe the surplus provided by networking mainly as access to different types of resources.

The analysis identified very active, moderately active, and passive-dormant relationships among network members, revealing also areas with deficits in networking. Dormant relationships together with the needs for professionalism and future orientation are challenges to be addressed. Meanwhile, networking in adult education proved to bring about organizational development, collective advances, and even competitive advantages in professional respects. 


\section{References}

Alke, Matthias. 2018. Kooperationskulturen von Weiterbildungsoranizationen zwischen Kontinuitaet und Wandel. Empirische Befunde und organizationspaedagogische Anschlüsse. Zeitschrift für Paedagogik 5: 659-679.

Antal, Zsuzsa. 2006. A szervezeti struktúra mint a stratégia megvalósítását támogató eszköz. Versenyképesség kutatások. Múhelytanulmány-sorozat 40. (http://edok. lib.uni-corvinus.hu/182/1/40_mht_antal_zs.pdf).

Becker, Brian, Gerhart, Barry. 1996. The Impact of Human Resource Management on Organizational Performance: Progress and Prospects. Academy of Management Journal 39: 779- 801.

Barabási, Albert-László. 2003. Behálózva. A hálózatok új tudománya. Budapest: Magyar Könyvklub.

Benedek, András, Csoma, Gyula, Harangi, László. 2002. Felnôttoktatási és képzési lexikon A-Z. Budapest: Szaktudás kiadó ház Zrt.

Biró, Zoltán A. 2013. Csíki-medence: térségi társadalmi körkép. In: Biró, Z. A., Magyar, F. (eds.), Vidék és versenyképesség. Agrárinnovációs helyzetkép a székelyföldi térségben. Miercurea Ciuc: Státus. 13-130.

Biró, Zoltán A., Sárosi-Blága, Ágnes. 2019. A szakképzés társadalmi elfogadása: tapasztalatok, megoldások. In: Köllő, Zs. (ed.), Erdélyi Magyar szakképzésfejlesztés - eredmények és lehetôségek. Miercurea Ciuc: RMPSZ. 35-46.

Burt, Eleanor, Taylor, John. 2000. Information and Communication Technologies. Nonprofit Management \& Leadership 2: 131-143.

Capozzi, Marla M., Lowell, Stephanie M., Silverman, Les. 2003. Knowledge Management Comes to Philanthropy. The McKinsey Quarterly 2. (http://ictkm. cgiar.org/Newsletter/McKinsey\%20Quarterly.htm).

Center for Regional and Anthropological Research. 2005. Adult Education - Social Background, Opportunities and Strategies. Working Paper. Miercurea Ciuc: Center for Regional and Anthropological Research.

Clayton, Berwyn, Fisher, Thea, Harris Roger, Bateman, Andrea, Brown Mike. 2008. Structures and Cultures: A Review of the Literature. Adelaide Australia: NCVER. (https://files.eric.ed.gov/fulltext/ED503353.pdf).

Darkenwald, Gordon G., Merriam, Sharan B. 1992. Adult Education: Foundations of Practice. New York: Harper\&Row.

Dobrai, Katalin, Farkas, Ferenc. 2010. Growing Professionalism in the Services of Non-Profit Organizations. Review of International Comparative Management 11: 894-904.

Farkas, Éva. 2013. A szak- és felnôttképzés gyakorlata. Szeged: SZTE JGYPK. (http:// eta.bibl.u-szeged.hu/688/1/tankonyv_farkas_eva_szakkepzes.pdf). 
Farkas, Ferenc, Dobrai, Katalin. 2009. Tudásalapú nonprofit szolgáltatások. In: Hetesi, E., Majó, Z., Lukovics, M. (eds.), A szolgáltatások világa. Szeged: JATEPress. 157-167.

Hall, Feyza. 2013. The Importance of Strategic Planning. (https://www.researchgate. net/publication/241688503_The_Importance_of_Strategic_Planning).

Hatos, Adrian, Andra, Berce (Brad). 2012. Sistemul de educație a adulților în România.

(https://docs.google.com/viewer?a=v\&pid=sites\&srcid=ZGVmYXVsdGRvb WFpbnxhZHJpYW5oYXRvc3xneDozN2EwNTU5OTBlYjFmYzJj).

Hunter, Judy. 2002. Improving Organizational Performance through the Use of Effective Elements of Organizational Structure. International Journal of Health Care Quality Assurance 15: xii-xxi.

Hwang, Hokyu, Powell, Walter W. 2009. The Rationalization of Charity: The Influences of Professionalism in the Nonprofit Sector. Administrative Science Quarterly 54(2): 268-298.

Kiss, Adél. 2009. Megyei felnőttképzési aktorok az Országos Felnőttképzési Jegyzékben. In: Bodó, J., Kiss, A. (eds.), Kultúra - kommunikáció - Innováció. Miercurea Ciuc: Státus. 115-123.

2011. Felnóttképzés és fejlesztés. Miercurea Ciuc: Hargita Népe.

2019. Felnőttképzési helyzetkép a székelyföldi térségben. METSZETEK 8(2): 93108.

Laki, László, Biró, Zoltán A. 2001. A globalizáció peremén. Kunhegyes térsége és a Csíki-medence az ezredfordulón. Budapest: MTA Politikai Tudományok Intézete.

McHargue, Susan K. 2003. Learning for Performance in Nonprofit Organizations. Advances in Developing Human Resources 2: 196-204.

Mintzberg, Henry. 1981. Organization Design: Fashion or Fit? Harvard Business Review 1-2: 103-116.

1989. Mintzberg on Management. Inside Our Strange World of Organizations. New York-London: Free Press-Collier McMillan.

Oláh, Sándor. 2006. Térség és kultúra. Miercurea Ciuc: Alutus.

Ostergaard, Lise Rosendal. 2005. To Network or Not to Network: NGO Experiences with Technical Networks (http://cercle.lu/download/partenariats/ AIDSNETnetworkornotnetwork.pdf).

Papp, Attila Z. 2005. Kihasználatlanul. A romániai magyar felnóttképzés rendszere. Miercurea Ciuc: Soros Oktatási Központ.

Ryan, William P. 1999. The New Landscape for Nonprofits. Harvard Business Review 1-2: 127-136.

Sandlin, Jennifer A., Clair, Ralf St. 2004. Volunteers in Adult Literacy Education. In: Comings, J., Garner, B., Smith, C. (eds.), Review of Adult Learning and Literacy. Mahwah NJ: Erlbaum. 125-154.

Sandu, Dumitru. 1999. Spațiul social al tranziției. Iaşi: Polirom. 
Sava, Simona. 2008. Trends in Adult and Continuing Education in Romania, a Country in Transformation. REPORT 2: 28-38. (https://www.die-bonn.de/doks/ sava0801.pdf).

Schifirneț, Constantin. 1997. Educația adulților în schimbare. Bucharest: Fiat Lux. Szigeti, Ferenc Albert. 2003. Az önkéntesség szerepe a fejlett piacgazdaságban. (http://www.3sz.hu/sites/default/files/uploaded/az_onkentesseg_szerepe_a_ fejlett_piacgazdasagban_szigeti_ferenc_albert_szakdolgozat_2003.pdf).

Vintanu, Nicolae. 1998. Educația aduților. Bucharest: Editura Didactică şi Pedagogică.

*** Association Pro Educatione, Organizational Strategy. www.proeducatione.ro. 